\title{
THE EFFECT OF MEDICAID EXPANSIONS IN THE LATE 1980S AND EARLY 1990S ON THE LABOR SUPPLY OF PREGNANT WOMEN
}

\author{
Dhaval M. Dave \\ Sandra L. Decker \\ Robert Kaestner \\ Kosali Ilayperuma Simon \\ Working Paper 19161 \\ http://www.nber.org/papers/w19161 \\ NATIONAL BUREAU OF ECONOMIC RESEARCH \\ 1050 Massachusetts Avenue \\ Cambridge, MA 02138 \\ June 2013
}

The authors thank Onur Altindag, Heather Dahlen, Chad Meyerhoefer and Asako Moriya for helpful comments. The findings and conclusions in this article are those of the author and do not necessarily represent the views of the Centers for Disease Control and Prevention or the National Bureau of Economic Research.

NBER working papers are circulated for discussion and comment purposes. They have not been peerreviewed or been subject to the review by the NBER Board of Directors that accompanies official NBER publications.

(C) 2013 by Dhaval M. Dave, Sandra L. Decker, Robert Kaestner, and Kosali Ilayperuma Simon. All rights reserved. Short sections of text, not to exceed two paragraphs, may be quoted without explicit permission provided that full credit, including $(\mathbb{C}$ notice, is given to the source. 
The Effect of Medicaid Expansions in the Late 1980s and Early 1990s on the Labor Supply of Pregnant Women

Dhaval M. Dave, Sandra L. Decker, Robert Kaestner, and Kosali Ilayperuma Simon

NBER Working Paper No. 19161

June 2013

JEL No. D1,I13,J01,J08,J22

\begin{abstract}
$\underline{\text { ABSTRACT }}$
A substantial body of research has found that expansions in Medicaid eligibility increased enrollment in Medicaid, reduced the rate of uninsured, and reduced the rate of private health insurance coverage (i.e., crowd out). Notably, there has been little research that has examined the mechanism by which crowd-out occurs. This study examines the effects of expansions in Medicaid eligibility for pregnant women in the late 1980s and the early 1990s on labor supply, which is one of the possible mechanisms underlying crowd out. Estimates suggest that the 20 percentage point increase in Medicaid eligibility during the sample period was associated with a $6 \%$ to $7 \%$ decrease in the probability that a woman who gave birth in the past year was employed. Among unmarried women with less than a high school education, the change in Medicaid eligibility reduced employment by approximately $13 \%$ to $16 \%$.
\end{abstract}

Dhaval M. Dave

Bentley University

Department of Economics

175 Forest Street, AAC 195

Waltham, MA 02452-4705

and NBER

ddave@bentley.edu

Sandra L. Decker

Distinguished Consultant

National Center for Health Statistics

Centers for Disease Control and Prevention

3311 Toledo Road (Room 6107)

Hyattsville, MD 20782

esp4@cdc.gov
Robert Kaestner

Institute of Government and Public Affairs

University of Illinois

815 West Van Buren Street, Suite 525

Chicago, IL 60607

and NBER

kaestner.robert@gmail.com

Kosali Ilayperuma Simon

School of Public and Environmental Affairs

Indiana University

Rm 359

1315 East Tenth Street

Bloomington, IN 47405-1701

and NBER

simonkos@indiana.edu 


\section{Introduction}

Employment and health insurance coverage are tightly linked in the United States because of the absence of a universal, public health insurance system and the tax deductibility of employer-provided health insurance benefits. As a result, a large majority of the non-elderly obtain health insurance coverage through their employers. However, for some segments of the population, specifically the elderly and the poor, government-financed health insurance is available. For the elderly, Medicare is a health insurance program that covers virtually all persons aged 65 and over. For the poor, Medicaid is a joint federal and state health insurance program that covers poor and near poor children and, to a more limited extent, the parents of these children. Participation in Medicaid has grown with expansions of the program and in 2011, nearly one-third of all children and nearly one-tenth of non-elderly adults are covered by Medicaid. ${ }^{1}$

The creation and expansion of public health insurance programs has generated interest in the effect of these programs on employment and employer-sponsored health insurance. Most research in this area has examined whether expansions in Medicaid have reduced the proportion uninsured and to what extent this reduction in uninsured was due to poor and near-poor families switching from private, employer-sponsored insurance to Medicaid (or similar programs such as the State Children's Health Insurance Program). Generally, evidence on this question indicates that the creation and expansion of Medicaid has resulted in a substantial decrease in the proportion uninsured and some substitution of public for private, employer-provided health insurance (i.e., crowd-out), although the extent of substitution is debated (Gruber and Simon

\footnotetext{
${ }^{1}$ Authors' calculations from the 2011 National Health Interview Survey. See http://www.cdc.gov/nchs/nhis.htm, website last accessed September 26, 2012.
} 
2008; Shore-Shepard 2008; Dave et al. 2011; Ham and Shore-Shepard 2005; LoSasso and Buchmueller 2004).

Notably, less research has been focused on the effect of publicly-provided health insurance on employment. Few studies have directly examined the effect of Medicare on employment because it is difficult to separate the effect of Medicare from other benefits, specifically social security, that occur at the same time as Medicare eligibility. However, several studies have examined how health insurance coverage affects employment among the elderly, and the evidence found in this literature implies that Medicare likely has a large effect on employment (Madrian 2007). For example, the availability of employer-provided health insurance after retirement is associated with earlier retirement (Strumpf 2010; Blau and Gilleskie 2008; Kapur and Rogowski 2007).

The literature examining the effects of Medicaid on employment is also relatively small. Much of it is concerned with the period of time when Medicaid was statutorily linked to the Aid to Families with Dependent Children (AFDC) program (i.e., prior to the Personal Responsibility and Work Opportunity Reconciliation Act of 1996). Very few studies have examined whether the expansion of Medicaid, independently of AFDC (or its replacement, Temporary Assistance for Needy Families - TANF) affected labor supply (Yelowitz 1995; Ham and Shore-Shepard 2005; Meyer and Rosenbaum 2001; Montgomery and Navin 2000). We review these papers in more detail below, but note here that the absence of more research on the effects of Medicaid on labor supply is surprising given the voluminous research on whether Medicaid has crowded out private health insurance. Crowd-out can occur in two ways: 1) by people changing labor supply choices such as whether and how much to work, or 2) by 
employees and employers changing health insurance offers or health insurance take up. ${ }^{2}$ There is a small literature on the latter mechanism, and results from it indicate, at most, small changes in insurance coverage from changes in insurance offer and take up rates. Thus, the absence of much research on whether Medicaid affected labor supply is noteworthy because without it, the mechanisms through which crowd-out occurred remain unknown and limits the ability of policymakers to address the issue effectively.

Our analysis of the effect of Medicaid expansions on pregnant women's labor supply is motivated by recent evidence reported by Dave et al. (2011) that Medicaid expansions targeted at pregnant women resulted in a substantial amount of crowd-out. Estimates reported in Dave et al. (2011) suggest that one out of every two pregnant women that enrolled in Medicaid during the late 1980s and early 1990s substituted public for private coverage. A key question for both theory and policy is what was the mechanism underlying the crowd out. Of course, multiple factors affect a woman's decision to work while pregnant or to return to the workforce after giving birth, such as the health of mother and child, family and workplace support, and the availability and cost of child care. In this paper, we examine whether the expansions of Medicaid to pregnant women that took place in the late 1980s and the early 1990s and that resulted in some substitution of public for private insurance by pregnant women occurred through changes in labor supply. Specifically, we provide the first estimates of the association between Medicaid expansions from 1985 to 1996, measured by proportion of the population eligible for Medicaid, and whether women with a child less than one year old (i.e., pregnant women) worked in the past year, their number of weeks worked in the past year, their usual

\footnotetext{
${ }^{2}$ Cutler and Gruber (1996) find effects of Medicaid on health insurance take up but do not find any effects of Medicaid on the probability that the employer offers health insurance. Buchmueller et al. (2005) also find little evidence that employers changed offers of health insurance, though they find some evidence of other adjustments such as increased employee contributions.
} 
hours of work per week in the past year, and their wages in the past year. Results of the analysis point to substantial changes in labor supply as the mechanism that explained crowd out. Estimates indicate that the 20 percentage point increase in Medicaid eligibility during the sample period was associated with a $6 \%$ to $7 \%$ decrease in the probability that a woman who gave birth in the past year was employed. Among unmarried women with less than a high school education, the change in Medicaid eligibility reduced employment by approximately $13 \%$ to $16 \%$.

\section{Literature Review}

Compared to the large literature on the insurance effects of Medicaid expansions, there is relatively little that has been written about its labor market effects. A few papers have examined the labor supply consequences of Medicaid policy for different time periods (the introduction of Medicaid in 1965, the expansion of Medicaid for children in the late 1980s/early 1990s) and different populations than ours (all women due to the expansions in coverage for their children rather than their own coverage while pregnant). Specifically, Decker and Selck (2011) examined the impact of Medicaid's introduction between 1966 and 1972 on welfare participation. Using aggregated state-level data, they found that the introduction of Medicaid increased AFDC caseloads. Investigating this effect further with individual-level analyses using data from the March Current Population Survey (CPS), Decker and Selck (2011) found that the increase in caseloads came from increases in take-up of Medicaid rather than from reductions in labor supply. Strumpf (2011) also used March CPS to examine labor supply decisions among single women in this period surrounding the introduction of Medicaid in the late 1960s. She also found no evidence that women likely to be eligible for the program reduced their labor supply. Taken together, these studies suggest that the creation of Medicaid made welfare more attractive for 
those already eligible for welfare (a take-up effect), perhaps through the value of the medical benefits overcoming some stigma and administrative hurdles that would have earlier existed.

Blank (1989) used the 1980 National Medical Care Utilization and Expenditure Survey (NMCUES) to study the issue and found that Medicaid eligibility did not affect AFDC participation (or, therefore, work). ${ }^{3}$ Winkler (1991) examined whether the availability of Medicaid for welfare recipients made welfare (and reduced work) more attractive to those who might not have chosen welfare if it did not provide health insurance through Medicaid. She used data from the 1986 March CPS and found that Medicaid availability reduced the probability of employment, but had no statistically significant impact on hours of work. Moffitt and Wolfe (1992) examined how Medicaid affected labor supply and welfare participation among single mothers using data from the 1984 wave of the Survey of Income and Program Participation (SIPP). They developed a family-specific proxy for the value of Medicaid and found that greater expected Medicaid spending was associated with lower participation in the labor market and higher participation in welfare.

Several studies examined the effect of Medicaid expansions in the 1980s and 1990s on female labor supply. Yelowitz (1995) assessed the impact of delinking welfare (AFDC) from Medicaid for children during the late 1980s and early 1990s on labor supply. He utilized the March CPS for 1989 to 1992 and examined the labor supply of single mothers aged 18-55 with at least one child under age 15. Yelowitz (1995) found that eligibility was associated with a decrease in welfare participation and an increase in labor force participation, with the effects being concentrated among separated or divorced women. In contrast to Yelowitz (1995), Ham and

\footnotetext{
${ }^{3}$ Although Blank (1989) found no impact of Medicaid on welfare participation in a cross section, analyses that exploit state-time variation in the introduction of Medicaid (Decker and Selck 2011 and Strumpf 2011) found that Medicaid increased welfare participation by making welfare more attractive for those already eligible. The methodological differences explain the contrast.
} 
Shore-Sheppard (2005) and Meyer and Rosenbaum (2001) found no significant association between labor supply and expanded Medicaid eligibility. Meyer and Rosenbaum (2001) found that increased labor force participation by single mothers could largely be explained by the expansion of the Earned Income Tax Credit (EITC), and to a lesser extent, welfare benefit cuts.

As this brief review highlights, the previous literature has reported mixed evidence on whether Medicaid is associated with a change in employment or hours of work. Studies that examined the expansions in Medicaid in the late 1980s that delinked Medicaid from AFDC found some evidence that Medicaid eligibility reduced labor supply (Winkler 1991; Yelowitz 1995). However, other studies of the same period reported no association between Medicaid eligibility and labor supply (Ham and Shore-Sheppard 2005; Meyer and Rosenbaum 2001). Finally, the only study that examined the most recent expansions in Medicaid (SCHIP) found that expansions were associated with a reduction in hours of work (Tomohara and Lee 2007).

The mixed findings of the effect of Medicaid on labor supply contrast with the uniformity of evidence related to "crowd-out"; while studies may differ in terms of magnitudes, almost all studies of "crowd-out" reported finding that Medicaid expansions are associated with a decline in employer-sponsored health insurance coverage. This decline in insurance can only come about through changes in labor supply or changes in offer and take-up rates of employer-sponsored insurance. The literature on the changes in offers of health insurance does not show evidence of employers ceasing to offer health insurance to the worker (Buchmueller et al. 2005, ShoreSheppard et al. 2000; and Cutler and Gruber 1996 ) The more limited literature on take-up suggests at most a small decline (Buchmueller et al., 2005). Therefore, it is likely that crowd out occurred because of changes in labor supply, but the evidence on this question is limited and 
inconclusive. This line of research may need to be investigated further, in addition to the possibility that Medicaid expansions affected labor supply decisions.

In this paper, we investigate the effect of the Medicaid expansions of the late 1980s and early 1990s on the labor supply of pregnant women. When Medicaid was enacted in 1965, it provided coverage primarily to those who qualified for cash welfare payments. Beginning in the early 1980s and particularly after 1987, eligibility for Medicaid coverage of the expenses of pregnancy and child birth was greatly expanded regardless of participation in welfare. These Medicaid expansions were first introduced as state options and later were mandatory if a state wanted to maintain their Federal Medicaid funding. By 1992, all states were required to cover the expenses of pregnancy and child birth for women in households with incomes up to $133 \%$ of the poverty line, and were permitted to extend eligibility up to $185 \%$ of the poverty line. As a result, the share of women who would be eligible for Medicaid coverage should they become pregnant rose from 20\% in 1986 to almost 45\% in 1992 (Currie and Gruber, 1996).

\section{Conceptual Framework}

The theoretical model we develop is based on the decisions of a mother who is choosing consumption, leisure, medical care and health insurance in a dynamic (two-period) model that spans the pre- to post-birth period. Health insurance is particularly important because it is used to buy medical care in order to improve maternal and infant health.

A woman's expected utility is a function of consumption, leisure and child health:

$$
E(U)=u_{0}\left(x_{0}, l_{0}\right)+\beta\left\{\left[1-\pi\left(m_{0}\right)\right]\left[u_{1}\left(x_{1}, l_{1}, c\right)\right]+\pi\left(m_{0}\right)\left[u_{1}\left(x_{1}, l_{1}, c-z\left(m_{1}\right)\right)\right]\right\}
$$

Equation (1) reflects the fact that there are two periods: prior to birth ( $\mathrm{t}=0)$ and after birth $(\mathrm{t}=1)$. Utility is a function of consumption (x), leisure (1) and child health (c) in each period, although in period 0 the child is not born and so child health does not enter the utility function. The 
discount rate is denoted by $(\beta)$. The model applies only to women who are pregnant; we assume that Medicaid has no effect on the pregnancy decision. ${ }^{4}$ Equation (1) also makes child health uncertain. With probability $(\pi)$, the child may experience an adverse health shock $(\mathrm{z})$ that lowers child health and can be offset (repaired) with medical care (m). Medical care can also be used to alter the probability of an adverse health event.

The woman's budget constraint is given by:

$$
x_{0}+p_{m}(\alpha) m_{0}+\frac{f}{\alpha}+\frac{x_{1}}{1+r}+\pi\left(m_{0}\right) \frac{p_{m}(\alpha) m_{1}}{1+r}+\frac{f}{\alpha} \frac{1}{1+r}=w(\alpha)\left(1-l_{0}\right)+\frac{w(\alpha)\left(1-l_{1}\right)}{1+r}=W
$$

Lifetime income is spent on: consumption $(\mathrm{x})$ in periods 0 and 1 ; medical care $(\mathrm{m})$ in periods 0 and 1 with price of medical care denoted by $p_{m}$; and the quantity of health insurance $(\alpha)$. The interest rate is denoted by $(r)$. Health insurance reduces the price of medical care and is financed out of earnings (w). The cost of health insurance also includes a loading charge $(f / \alpha)$ where $f$ is a fixed cost of administering health insurance.

The constrained choice problem is given by:

$$
\begin{aligned}
L= & u_{0}\left(x_{0}, l_{0}\right)+\beta\left\{\left[1-\pi\left(m_{0}\right)\right]\left[u_{1}\left(x_{1}, l_{1}, c\right)\right]+\pi\left(m_{0}\right)\left[u_{1}\left(x_{1}, l_{1}, c-z\left(m_{1}\right)\right)\right]\right\} \\
& -\lambda\left[x_{0}+p_{m}(\alpha) m_{0}+\frac{f}{\alpha}+\frac{x_{1}}{1+r}+\pi\left(m_{0}\right) \frac{p_{m}(\alpha) m_{1}}{1+r}+\frac{f}{\alpha} \frac{1}{1+r}-w(\alpha)\left(1-l_{0}\right)-\frac{w(\alpha)\left(1-l_{1}\right)}{1+r}\right.
\end{aligned}
$$

The first order conditions for consumption, leisure, medical care and insurance, respectively, are given by:

\footnotetext{
${ }^{4}$ Given the mixed evidence on this issue, we simplify the analysis by assuming it is zero. For instance, Joyce et al. (1998), using pooled cross-sections of states, find that expansions in the income thresholds for Medicaid eligibility between 1987-1991 are associated with a 5\% increase in the birthrate among white women but not among black women. They also find some evidence of a significant decline in the abortion rate, suggesting that the increase in birthrate may be due to a decrease in abortions rather than an increase in pregnancies. DeLeire et al. (2011) find no discernible effects on fertility from Medicaid expansions using Natality data from 1985-1996. Zavodny and Bitler (2010) find little evidence that the expansions had any effect on abortion or pregnancy rates examining state-level birth and abortion rates between 1982-1996.
} 


$$
\begin{aligned}
& \text { (4) } \frac{\partial L}{\partial x_{0}}=u_{0 x}-\lambda=0 \quad \frac{\partial L}{\partial x_{1}}=\beta\left[(1-\pi) u_{1 x}+\pi \widetilde{u}_{1 x}\right]-\lambda \frac{1}{1+r}=0 \\
& \widetilde{u}_{1}=u_{1}\left(x_{1}, l_{1}, c-z\right) \\
& \text { (5) } \frac{\partial L}{\partial l_{0}}=u_{0 l}-\lambda w(\alpha)=0 \quad \frac{\partial L}{\partial l_{1}}=\beta\left[(1-\pi) u_{1 l}+\pi \tilde{u}_{1 l}\right]-\lambda \frac{w(\alpha)}{1+r}=0 \\
& \frac{\partial L}{\partial m_{0}}=\beta \frac{\partial \pi}{\partial m_{0}}\left(\tilde{u}_{1}-u_{1}\right)-\lambda\left[p_{m}(\alpha)+\frac{\partial \pi}{\partial m_{0}} \frac{p_{m}(\alpha) m_{1}}{1+r}\right]=0 \\
& \beta \frac{\partial \pi}{\partial m_{0}}\left(\tilde{u}_{1}-u_{1}\right)=\lambda\left[p_{m}(\alpha)+\frac{\partial \pi}{\partial m_{0}} \frac{p_{m}(\alpha) m_{1}}{1+r}\right] \\
& \text { (6) } \\
& \frac{\partial L}{\partial m_{1}}=-\beta \pi \frac{\partial u_{1}}{\partial c} \frac{\partial z}{\partial m_{1}}-\lambda \pi \frac{p_{m}(\alpha)}{1+r}=0 \\
& -\beta \frac{\partial u_{1}}{\partial c} \frac{\partial z}{\partial m_{1}}=\lambda \frac{p_{m}(\alpha)}{1+r} \\
& \frac{\partial L}{\partial \alpha}=-\lambda\left[\frac{\partial p_{m}}{\partial \alpha} m_{0}-\frac{f}{\alpha^{2}}+\pi \frac{\partial p_{m}}{\partial \alpha} \frac{m_{1}}{1+r}-\frac{f}{\alpha^{2}} \frac{1}{1+r}-\frac{\partial w}{\partial \alpha}\left(1-l_{0}\right)-\frac{\partial w}{\partial \alpha} \frac{\left(1-l_{1}\right)}{1+r}\right]=0 \\
& \text { (7) }-\frac{\partial p_{m}}{\partial \alpha}\left(m_{0}+\pi \frac{m_{1}}{1+r}\right)=-\frac{f}{\alpha^{2}}\left(1+\frac{1}{1+r}\right)-\frac{\partial w}{\partial \alpha}\left[\left(1-l_{0}\right)+\frac{\left(1-l_{1}\right)}{1+r}\right] \\
& \frac{\partial w}{\partial \alpha}\left[\left(1-l_{0}\right)+\frac{\left(1-l_{1}\right)}{1+r}\right]-\frac{\partial p_{m}}{\partial \alpha}\left(m_{0}+\pi \frac{m_{1}}{1+r}\right)=-\frac{f}{\alpha^{2}}\left(1+\frac{1}{1+r}\right)
\end{aligned}
$$

Given the above framework, we examine the effect of Medicaid on a woman's decisions.

Medicaid provides free health insurance $(\alpha)$, which in this model is the same as setting $\mathrm{f}=0$ and $\frac{\partial w}{\partial \alpha}=0$ at least for those women with w less than some amount (income eligible).

We begin with women who have private health insurance $(\alpha>0)$ who are working by definition (as they have private own-name coverage) in a counterfactual world of no Medicaid expansion (i.e. would not find it desirable or possible to have reduced labor supply and joined Medicaid absent the expansion). These women experience an increase in wage upon receiving Medicaid instead of employer health insurance because Medicaid does not have to be financed 
out of earnings. As shown by equation (5), an increase in the wage will cause them to work more in both periods because of the substitution effect. However, it is plausible that the marginal utility of leisure increases post-birth and thus the increase in work would be larger prior to birth than after birth. Importantly, an increase in wage can only be obtained by changing jobs (to an employer who does not provide insurance) or by dropping insurance obtained from the current employer. There is also an income effect associated with Medicaid availability that reduces work effort in both periods. Thus, among women with private coverage and who are working, the new availability of Medicaid may increase or decrease work effort and accompany a switch from private to public insurance. The income effect is likely to dominate for those with a higher probability of an adverse birth outcome (sick) and/or high use of medical care (preferences for child quality) because these persons will use more medical care that requires greater loss of income. The income effect will also dominate in the post-birth period particularly for those with a high value of child rearing. Therefore, we expect expanded Medicaid eligibility to be associated with movement from employed with private insurance to employed with public insurance, and from employed with private insurance to not employed with public insurance. The latter change to non-employment may be particularly likely post-birth with the plausible increase in the marginal utility of leisure. While we have expressed changes in terms of employment, labor supply could also be altered through the intensive margin of hours of work. The ambiguity with respect to changes in employment also applies to hours of work.

Women who are without private insurance $(\alpha=0)$ and employed experience an income effect and work less. They were not financing insurance from wages to begin with, so there is no wage change. The income effect is largest for those with a higher probability of an adverse birth outcome (sick) and/or high use of medical care (preferences for child quality). Therefore, we 
expect movement from uninsured/employed to public insurance/employed and to public insurance/not employed. For this group too, we expect the latter change to non-employment to be particularly likely post-birth.

One question that arises from the previous analysis is why do some women who work have different levels of insurance (insured-uninsured)? As shown by equation (7), insured persons are those with a low "f", small $\frac{\partial p_{m}}{\partial \alpha}$ and/or high $\frac{\partial w}{\partial \alpha}$. Persons may be uninsured if they work in a small firm in which the loading cost is relatively high, or if the generosity of insurance $\left(\frac{\partial p_{m}}{\partial \alpha}\right)$ is low relative to the wage cost of insurance $\left(\frac{\partial w}{\partial \alpha}\right)$. We simply assume there is an insurance market that will equate expected expenditures with premiums.

Women who do not work, and are uninsured, experience an income effect, but this has no labor supply effect because they do not work. These women move from uninsured to public insurance with no change in work status. Finally, women who are not working and insured (e.g., public insurance through AFDC) experience a wage increase over some range of income that allows them to remain eligible for Medicaid. Because these women do not have to finance insurance through wage decreases, they will be more likely to work because of the higher wage. Therefore, we expect movement from not employed with public insurance (AFDC) to employed with public insurance (Medicaid).

Our model differs from Yelowitz (1995) because we assume that individuals finance health insurance through wages. Thus, the availability of public insurance changes the wage and price of leisure for those who work and are insured privately. By contrast, Yelowitz assumes that there is no one in this category. For those who work and are uninsured, there is the same income effect. For those who do not work and are uninsured the same applies. 
To summarize, based on the above paradigm, we expect expanded Medicaid eligibility to be associated with:

- movement from employed with private insurance to employed with public insurance, and from employed with private insurance to not employed with public insurance;

- movement from uninsured/employed to public insurance/employed and to public insurance/not employed;

- movement from uninsured to public insurance with no change in work status;

- and movement from not employed with public insurance (AFDC) to employed with public insurance (Medicaid).

Although our model is designed to apply to pregnant women, some expectations above may also be true for expansions of public insurance to other groups, though movement particularly in the first category above may be less for other groups if they have lower elasticities of labor supply/lower marginal utility of leisure compared to pregnant women.

\section{Research Design}

Our analysis is motivated by the incentives described above for pregnant women to potentially reduce their labor supply in response to the availability of health insurance coverage that is not tied to the labor market, incentives which increased with the expansion in Medicaid eligibility. Accordingly, the empirical models are specified to obtain estimates of the effect of the Medicaid expansions on labor market outcomes and on the joint probability between labor market outcomes and health insurance.

First, for each type of labor market outcome (L), we estimate the following regression model: 


$$
\begin{array}{ll}
L_{i k j t}=\alpha_{j}+\beta_{t}+\delta E L I G_{k j t}+X_{i} \Gamma+Z_{j t} \lambda+u_{i k j t} \\
\mathrm{i}=1, \ldots, \mathrm{N} & \text { (persons) } \\
\mathrm{k}=1,2,3 & \text { (race) } \\
\mathrm{j}=1, \ldots 50 & \text { (states) } \\
\mathrm{t}=1985, \ldots 1996 & \text { (years) }
\end{array}
$$

In equation (8), $\mathrm{L}$ is a specific labor market outcome (employed, labor force participation, weeks worked, hours worked, wages) for woman $i$ in state $j$ and year $t$; ELIG is the fraction of women in group $\mathrm{k}$, which is defined by race, in state $j$ and year $t$ that are eligible for Medicaid; $\mathrm{X}$ are individual characteristics of pregnant women such as age, education, and race; and Z are timevarying state-level characteristics including the unemployment rate, poverty rate, and fraction of single males with incomes below $200 \%$ of the federal poverty line (FPL) with private insurance in state $j$ and year $t^{5}$ Equation (1) includes state $\left(\alpha_{\mathrm{j}}\right)$ and year $\left(\beta_{\mathrm{t}}\right)$ effects. We chose to define our group cells by race, in addition to state and year, because of the large racial differences that exist in insurance coverage and labor market behaviors. We estimate models for employment, labor force participation and wages by ordinary least squares and models for hours and weeks worked by negative binomial regression methods. All models account for the sampling weights provided in the Current Population Survey, and standard errors are adjusted for arbitrary correlation within state cells (Moulton 1990; Donald and Lang 2007).

The use of the fraction of women eligible for Medicaid in each state and year to measure Medicaid eligibility follows the innovation of Currie and Gruber (1996) and Cutler and Gruber (1996). The key to this measure is that it records the fraction of a fixed sample of women (usually drawn nationally) who would be eligible for Medicaid if they were pregnant and lived in

\footnotetext{
${ }^{5}$ The fraction of single males with incomes below $200 \%$ of the FPL who are privately insured in each state/year is computed from the March Current Population Surveys.
} 
each state in each year, avoiding the endogenous relationship between Medicaid eligibility of an individual mother and her labor supply or the health of that mother or her infant. To form the measure, we select a sample of women aged 18 to 39 from the 1986 to 1997 March Current Population Surveys (CPS) (covering data from 1985-1996). We adjust all financial variables for price changes such that incomes are deflated (inflated) from the actual year (e.g., 1985,..,1996) to the policy year (e.g., 1988) for which eligibility will be calculated. Using these inflationadjusted state-specific samples and the Medicaid eligibility rules in a state in a specific year, we assign eligibility to the (fixed) state sample so that eligibility is calculated using the same sample of women in each year for a given state. ${ }^{6}$ We then calculate the proportion of women aged 18 to 39 within a race-state-year cell that would be eligible for Medicaid if they became pregnant. The variation in this measure comes from program rules alone--once inflation adjustments are made, the only way the percent eligible in this fixed sample changes is due to changes in the state eligibility rules. This variable - the fraction of women that would be eligible for Medicaid conditional on pregnancy — is merged with the March CPS records by year, state and race. As documented in Currie and Gruber (1996), Federal mandates during the late 1980s and early 1990s resulted in large increases in all states in the fraction of women who would be eligible for Medicaid if pregnant, though the magnitude of the increase varied widely according to initial eligibility limits and state decisions about whether to go beyond Federally mandated minimum eligibility increases.

\footnotetext{
${ }^{6}$ Currie and Gruber (1996) and Cutler and Gruber (1996) use a national sample instead of state-specific samples. However, given that the measure is based on state variation in the timing and magnitude of Medicaid expansions, using state-specific samples introduces no additional variation that would bias estimates. Any endogeneity from the state income distribution is purged through the state fixed effects. State samples will produce less measurement error, which is relevant to the correlation between eligibility and insurance.
} 
We modify the basic model in several ways to address specific issues. First, in supplementary models we include state-specific time trends to adjust for the less than perfect nature of the natural experiment. Inclusion of state-specific time trends (set of state fixed effects that are interacted with a linear measure for time in years) adjusts for the potential endogeneity of the Medicaid expansions if states with greater expansions have correlated linear time trends in labor force participation for other reasons. Second, we assess differential effects by estimating models that interact Medicaid eligibility with marital status and educational attainment. Here, we exploit the fact that certain subgroups of the population are more likely to be affected by shifts in Medicaid policy. For instance, those mothers with relatively less education or who are unmarried have higher Medicaid take-up rates and larger changes in insurance coverage than those with more education or who are married because the latter groups are unlikely to be affected by the eligibility expansions. Thus as a plausibility check, if Medicaid eligibility expansions are found to impact labor market behavior, we expect stronger effects among unmarried and low-educated mothers. We also assess differential effects across first pregnancy and across later pregnancies.

Third, we directly test the predictions of the conceptual framework by modeling the joint probability between shifts in labor market outcomes and health insurance status. Specifically, we define six inclusive categories that cover the following joint outcomes: 1) currently employed with private insurance; 2) currently employed with public insurance; 3) currently employed with no insurance; 4) not employed with private insurance; 5) not employed with public insurance; and 6) not employed with no insurance. Based on these mutual outcomes, we estimate the effects of the Medicaid eligibility expansions on the joint probability of employment and health insurance status via multinomial logit regression. 
Finally, we implement some additional specification checks to assess the robustness and plausibility of our labor supply effects. We estimate models with interactions between age group and year fixed effects and between age group and state fixed effects because prior studies on children's Medicaid suggest results that were sensitive to the inclusion of age trends. ${ }^{7}$ We also implement a placebo test by relating the eligibility expansions to the labor supply of loweducated single males. We calibrate the labor supply effects to assess whether they are potentially consistent with the magnitude of the crowd-out effects identified in the literature for pregnant women.

\section{Data}

We use the March CPS for the analyses because it contains the largest sample sizes among any available datasets that contain information on labor market outcomes of pregnant women. ${ }^{8}$ We use data spanning 1986-1997. Pregnant women in the CPS are identified as women who have children under the age of one at the time of the survey. We limit the sample to women who gave birth from 1985 - 1996 when they were between the ages of 18-39.

Labor supply was measured in several ways: 1) an indicator for whether the woman was employed during the year that she gave birth; 2) an indicator for whether the woman was in the labor force during the year that she gave birth; 3) weeks worked during the year that she gave birth; 4) usual hours worked per week during the year that she gave birth; and 5) wage and salary income during the year that the woman gave birth. Our sample sizes range from 22,182 to 23,043 pregnant women who gave birth between 1985 and 1996.

\footnotetext{
${ }^{7}$ Coefficient magnitudes are also robust to controlling for interactions between race indicators and year/state effects, which account for differential race-specific trends and local labor market conditions (results available upon request). ${ }^{8}$ The Survey of Income and Program Participation (SIPP) contains only about 1000 pregnant women per survey year (or about 12,000 over our sample period), and the Panel Study of Income Dynamics (PSID) contains even fewer pregnant women. The Behavioral Risk Factor Surveillance System (BRFSS) would potentially yield larger sample sizes; however, it is limited over the period experiencing the largest Medicaid eligibility expansions for pregnant women (1985-1996), since 1994 was the first year that all states participated in the survey.
} 
The CPS is also used to calculate the fraction of women eligible for Medicaid by race, state and year, which is the key independent variable and described in the previous section. We match this measure of Medicaid eligibility to the CPS records by the woman's race, state of residence, and the year that she gave birth. The CPS is further used to compute the fraction of single men aged 25 to 64 who have incomes below $200 \%$ of the FPL and are privately insured by state and year, which serves to control for trends in health insurance coverage by state.

One limitation of the CPS (which is not unique to the CPS) relates to the timing of the pregnancy and the reference period over which labor market outcomes are measured. For instance, consider the 1990 March CPS. Our sample for this year consists of mothers whose child was born between April 1989 and March 1990 and these mothers were pregnant between August 1988 and July 1989. Their labor market outcomes (and insurance status) refer to the past calendar year, which is 1989. For women with children close to one year of age (born April 1989), we will be measuring labor market outcomes during the mother's last 4 months of pregnancy and the first 8 months of the child's life. For women with children less than a month old (born March 1990), we will be measuring outcomes 6 months prior to pregnancy and during the first two trimesters. Based on the observed distribution of births across months (obtained from the U.S. vital statistics) between 1985 and 1996, we will be measuring labor market outcomes during an average mother's almost entire pregnancy and approximately the first 3 months of the child's life. If the pregnant woman does not change her labor force status after the child is born up to the first 3 months, this timing issue should not bias our estimates. If a pregnant woman who has dropped out of the labor force while pregnant, induced by the availability of Medicaid, returns back to work during the first 3 months after giving birth, then the partial mismatch in the reference period would introduce attenuation bias to our estimates. 
We therefore interpret our effects as lower-bound conservative estimates of the impact of the Medicaid eligibility expansions on pregnant women's labor market behavior.

Table 1 presents sample means and proportions. This table contains weighted sample means of our data for all years and separately for subgroups based on marital status, education, and race. On average, $22.1 \%$ of pregnant women were eligible for Medicaid coverage over our sample period; this eligibility increased from $9.7 \%$ in 1985 to $31.1 \%$ in 1996 (See Figure 1). Actual reports of Medicaid coverage increased by about 13 percentage points, and the prevalence of private insurance coverage decreased by over 6 percentage points in the CPS, consistent with crowd-out. Based on the National Hospital Discharge Surveys, actual Medicaid status at delivery increased by 15.7 percentage points over this period, coincident with the expansions in eligibility, whereas private coverage declined by 6 percentage points (Dave et al. 2011).

\section{Regression Results}

Table 2 presents estimates of the effect of expanding Medicaid eligibility on the employment status, labor force participation, and weeks worked among pregnant women during the year of childbirth, corresponding to estimates of $\delta$ in Equation (8). For each type of labor market outcome, we estimate models with and without state-specific linear trends. Our preferred estimates are the ones including state trends, though it is reassuring that magnitudes of estimates are not very sensitive to these controls.

Estimates in Table 2 indicate that Medicaid eligibility is negatively and significantly associated with labor supply. ${ }^{9}$ Specifically, estimates in columns 1 and 2 suggest that a 20 percentage point increase in Medicaid eligibility, which is the approximate change that occurred over the 1985 to 1996 period, is associated with a 4.1 (with state trends) to 4.4 (without state trends) percentage points decrease in the probability of employment. This is approximately a $7 \%$

\footnotetext{
${ }^{9}$ Although not reported, parameter estimates are robust to logit or probit estimation for the dichotomous outcomes.
} 
decline relative to the baseline mean prevalence of working. These effects are statistically significant at the one-percent level. With respect to labor force participation, estimates in columns 3 and 4 suggest a virtually identical decline in labor force participation as in employment; the reduced probability of working was driven not by an increase in unemployment (which would not be consistent with pregnant women reducing work effort due to the offer of health insurance that is no longer tied to the labor market), but rather by these women choosing to drop out of the labor force. Estimates in columns 5 and 6, which are obtained from negative binomial regressions models, suggest that a 20 percent point increase in Medicaid eligibility reduced weeks worked by between $6.8 \%$ (with state trends, though imprecisely estimates) and $8.0 \%$ (without state trends).

Table 3 examines shifts in weekly hours worked and annual wages. Estimates in columns 1 and 2 indicate that a 20 percentage point increase in Medicaid eligibility reduced weekly hours by about $10.2 \%$ to $10.5 \%$. The next set of estimates (columns 3 and 4 ) explore whether this reduction in labor supply occurred at the extensive or intensive margins by restricting the analyses to individuals with positive hours worked. Estimates in these columns decline substantially and suggest that virtually all (almost 80-85\%) of the effect on hours worked is at the extensive margin, that is, the reduction is driven by a decrease in employment and dropping out of the labor force rather than a decrease in labor supply among women continuing to work. Estimates in columns 5-6 pertain to the effect of Medicaid eligibility on wages (including zero wages), whereas the final two specifications estimate effects on wages and are for a sample with positive wages. ${ }^{10}$ As with hours worked, we find significant negative effects on wages (52.5\% reduction owing to a 20 percentage point increase in eligibility) with almost all

\footnotetext{
${ }^{10} \mathrm{We}$ assign a value of $\$ 0.10$ to individuals who have zero wages prior to the log transformation in models 5 and 6 , in order to examine effects on the wages of all women (including those who do not work). In models 7 and 8 , we omit these women with zero wages from the analyses.
} 
of this effect being realized at the extensive margin (women shifting from positive to zero wages).

The effects of the other covariates in Tables 2 and 3 are generally consistent with the literature. Relative to married women, unmarried pregnant women are more likely to be working, work more weeks and hours per week, and have higher wages. Labor supply and income decline significantly for low-educated individuals relative to high-school graduates and above. Relative to whites, black pregnant women supply more labor and have higher income.

Some prior studies on children's Medicaid (for instance, Shore-Sheppard 2008) suggest that estimates of insurance crowd-out may be sensitive to age trends. For analyses of child health insurance, Medicaid eligibility differs by age. In our case, age is arguably not relevant because Medicaid eligibility rules for pregnant women do not depend on the mother's or the child's age. Table 4 confirms that the labor supply estimates are not sensitive to controlling for indicators for state by age-of-mother and year by age-of-mother interactions. ${ }^{11}$ Similar to the effects noted above, a 20 percentage point increase in eligibility is associated with a 4.0 percentage points decline ( $6 \%$ decline relative to the baseline mean) in employment and labor force participation, an $7.8 \%$ decline in weeks worked, and a $10.0 \%$ decline in weekly hours worked.

The above analyses pertain to all pregnant women between the ages of 18-39. However, subgroups of the population are relatively more likely to be affected by the Medicaid eligibility expansions. Low-educated or unmarried mothers have higher Medicaid take-up rates and larger changes in insurance coverage relative to those who are married or with more education because these latter groups are far less likely to be affected by the eligibility expansions. For instance, in

\footnotetext{
${ }^{11}$ We also confirm that our estimates are robust to the inclusion of indicators for state*race and year*race interactions (results not reported).
} 
the CPS sample, Medicaid participation among pregnant women with less than a high school education is 2.4 times greater relative to higher educated women, and 6.1 times higher among unmarried pregnant women relative to those who are married. Therefore, we expect somewhat larger effects of Medicaid eligibility on the labor supply of unmarried and low-educated pregnant women.

Table 5 assesses this hypothesis by estimating models that allow the effect of Medicaid eligibility to differ by marital status (unmarried) and education (less than high school graduates). Estimates in columns 1 and 2 in the top panel of Table 5 indicate that a 20 percentage point increase in Medicaid eligibility reduces employment by significantly more among unmarried women (close to 7 percentage points in models with state trends) relative to married women (2.4 percentage points). A similar pattern and effect magnitudes are expectedly found for labor force participation (columns 3 and 4). To place these effect sizes in context, these estimates indicate that a 20 percentage point increase in Medicaid eligibility is associated with an $11 \%$ to $13 \%$ decrease in the probability of working and labor force participation among unmarried pregnant women. With respect to weeks worked in the year of birth (columns 5 and 6) and usual weekly hours worked (columns 7 and 8), estimates suggest small and insignificant declines among married pregnant women, but far stronger and significant effects among unmarried pregnant women (decline of $13-16 \%$ in models with state trends). In supplementary specifications (not reported), we confirm that most of this labor supply effect is realized at the extensive margin. The bottom panel of Table 5 presents differential effects for pregnant women with less than a high school education relative to more educated women. Focusing on estimates from models that include state trends, results suggest that an increase in Medicaid eligibility similar to that experienced over $1985-1996$ is associated with a $14 \%$ to $16 \%$ decrease in the probability of 
employment and labor force participation among low-educated women; this compares to a statistically insignificant 1.3-1.8 \% decrease among higher-educated women. Weeks employed and weekly hours worked declined by approximately $20 \%$ among low-educated pregnant women, with no negative effect on women who are at least high-school graduates. Estimates for log wages (not reported) suggest a similar pattern of results as above. Overall, estimates in Table 5 bolster the plausibility of our findings because they confirm that the effects of Medicaid eligibility on labor supply and wages are being driven by behavioral changes among women who are most likely to be affected by Medicaid policy. Effects on other population groups (highereducated and married women), who are at low-risk of Medicaid take up, are minimal and generally insignificant.

Women giving birth for the first time may have less information regarding the benefits available, in which case the Medicaid expansions could induce a smaller labor supply response. Women with children may also place a higher value on non-work time, and the Medicaid subsidy is larger for them relative to first-time pregnant women. Labor supply decisions may also change in different ways when there are already younger kids at home. We therefore assess whether there are differential effects of Medicaid on labor supply by whether a women was giving birth for the first time or not. Estimates for this analysis are reported in Table 6. Across all labor supply measures, for both groups of mothers, we find that the eligibility expansions led to a reduction in work. With respect to employment, the effect sizes are similar across both groups of pregnant women. For labor force participation and weeks of employment, the magnitudes of estimates suggest somewhat larger effects among women who are not first-time mothers, while the decline in usual hours worked is somewhat great among first-time mothers. However, due to 
relatively large standard errors resulting from a reduced sample size, we are not able to reject the null of similar effects across both groups for most of the labor supply outcomes.

The next set of results we present are estimates of the effects of the Medicaid eligibility expansions on the joint probability of employment status and health insurance. Theory predicts that expanded Medicaid eligibility would be associated with a movement of pregnant women from employed with private insurance to employed with public insurance, and from employed with private insurance to non-employed with public insurance. Estimates for this analysis were obtained from multinomial logit regression models and are presented in Table 7. We present estimates for two sets of labor supply outcomes, employment (Panel A) and labor force participation (Panel B), and for models with and without state-specific trends. Estimates are highly similar across all of these specifications; hence, we discuss the employment models that control for state-specific trends and scale all estimates in the discussion to correspond to a 20 percentage points increase in Medicaid eligibility.

Estimates in Table 7 generally confirm the model's prediction. Specifically, we find that a 20 percentage point increase in Medicaid eligibility is associated with a 7.2 percentage points reduction in the probability of being employed with private insurance and a 1.7 percentage points increase in the probability of being employed with public insurance. A 20 percentage point increase in Medicaid eligibility is also associated with a 2.6 percentage point increase in the probability of not being employed with public insurance. All of these results are consistent with theoretical predictions and estimates on which they are based are statistically significant. However, estimates in Table 7 also indicate that the Medicaid eligibility expansions were associated with an increase in uninsured, which is unexpected from a theoretical perspective, although not all estimates are statistically significant. One explanation for this result is 
measurement error. As noted, the health insurance and labor force information in the CPS refers to the past year, which overlaps the period pre- and post-birth for most women in our sample. In addition, in the case of health insurance, researchers suspect that many women respond as to their status with reference to the current period (not the case for labor force). Thus, these data problems may account for the anomalous estimates, but we cannot rule out the possibility that these estimates may be indicative of a less than perfect research design despite the overall consistency of our estimates and the explicit test of the research design we discuss next.

Finally, Table 8 presents estimates form a falsification analysis. Here we estimate models among low-educated unmarried males between the ages of 18-39, for whom expansions in Medicaid eligibility for pregnant women should have virtually no effect on labor supply. Indeed, we do not find any economically meaningful or statistically significant effects of Medicaid eligibility on their labor supply, which adds a degree of confidence to the specification choice and suggests that the expansions are not correlated with time-varying state-specific unobservable, conditional on all the observed covariates and fixed effects.

\section{Discussion}

State and Federal governments have dramatically expanded Medicaid over the past two decades to provide insurance for an increasingly large proportion of poor and near-poor persons. While expansion of Medicaid may impart several benefits besides providing insurance (e.g., consumption smoothing), an important rationale for expansion is that it will decrease the proportion of the population that is uninsured and, as a result, increase use of health care services and improve health.

Studies have found that the Medicaid expansions of the late 1980s and early 1990s were associated with a significant and relatively large increase in Medicaid participation, but 
substantially smaller decreases in the proportion uninsured because a large fraction of the newly enrolled Medicaid participants previously were privately insured (Dave et al. 2011; Dubay and Kenney 1997). Both of these studies, utilizing different datasets and methods, suggest a crowdout rate of about $50 \%$-- that is, about half of the increase in Medicaid participation came from individuals who previously had private insurance..$^{12}$

As the Medicaid expansions had a smaller effect in reducing the number of uninsured than in increasing Medicaid coverage (Dave et al., 2011), the ability of Medicaid to influence infant health through increased access to care for uninsured mothers was lower than hoped. For this reason, and because crowd-out of private insurance reduces the cost-effectiveness of expanding public insurance, it is important to understand the mechanisms by which this crowd-out occurs.

Among pregnant women, the primary mechanism that leads to crowd-out was through a reduction of labor force participation. We find robust evidence that expansions in Medicaid eligibility targeted at pregnant women were associated with a reduction in their labor force participation, and the decrease in labor force participation, work effort, and income was concentrated almost exclusively among low-educated and unmarried pregnant women -individuals who conventionally have higher Medicaid take-up rates and therefore more likely to be affected by shifts in Medicaid policy. Specifically, we find that a 20 percentage point increase in Medicaid eligibility was associated with a 6.9 percentage point (13\% relative to baseline work status) decline in employment among unmarried pregnant women. About 49.7\% of unmarried (and 74.0\% of low-educated) employed pregnant women ages 18-39 in the 1986 to 1997 CPS had employer-provided health insurance. Combining this prevalence with our labor

\footnotetext{
${ }^{12}$ A sizeable literature also suggests significant crowd-out effects among families and children, along the same order of magnitude (see Gruber and Simon 2008).
} 
supply estimates suggests that a 20 percentage point increase in Medicaid eligibility reduced private coverage by about 3-4 percentage points among unmarried pregnant women and by about 5-6 percentage points among low-educated pregnant women. These magnitudes of decline in private insurance coverage are in line with estimates from the crowd-out studies that have specifically focused on pregnant women. Dave et al. (2011), for instance, find that the Medicaid eligibility expansions over the same time period analyzed in this study reduced private insurance coverage among pregnant women by 4-5 percentage points. Dubay and Kenney (1997), analyzing simple trends, find that private insurance coverage among near-poor pregnant women declined by 7.5 percentage points (relative to men) over 1988-1992.

We note that the reduction in labor supply associated with the Medicaid expansions can come from working pregnant women who have private coverage, which would drive crowd-out of private for public coverage, and also from working but uninsured pregnant women, in which case the change in labor supply would not be associated with crowd-out - and indeed, we do find some evidence of these shifts based on multinomial logit modeling of the joint probability of employment and insurance outcomes. Nevertheless, these models also suggested that the largest shift in mass among pregnant women was from employed with private coverage to nonemployed with public coverage. Furthermore, the consistency of our labor-supply estimates in generating observed declines in private coverage plausibly points to shifts in employment as a key driving mechanism behind the crowd-out of private coverage among pregnant women due to the expansions in Medicaid eligibility.

We did not, however, address the duration of reductions in employment starting during pregnancy or the net benefit for children who may have their mothers home during early life but live at least for a while in families with lower income. The net effect of mother's work force 
participation on the welfare of mother and baby is unknown. We were also not able to explore the effects of expansions in Medicaid eligibility to non-pregnant women or to men since these populations were not extended Medicaid benefits during the time period analyzed. These groups may be less likely to change labor force participation due to the availability of Medicaid or other insurance outside of work, especially since they may have lower labor supply elasticities in general (Evers, De Mooij, and Van Vuuren, 2008). We also did not investigate the effect of changes in children's Medicaid eligibility on parental labor supply. These may be questions for future research. 


\section{References}

Blank, R. 1989. "The Effect of Medical Need and Medicaid on AFDC Participation.” Journal of Human Resources. Vol 24(1):54-87. Winter 1989.

Blau, David M. and Donna B. Gilleskie. 2008. "The Role of Retiree Health Insurance in the Employment Behavior of Older Men.” International Economic Review 49(2): 475-514

Buchmueller, T., P. Cooper, K. Simon and J. Vistnes. 2005. "The Effect of SCHIP Expansions on Health Insurance Decisions by Employers". Inquiry 42(3):218-31.

Chatterji, Pinka and Sara Markowitz. 2013. "Effects of Early Maternal Employment on Maternal Health and Well-being. " Journal of Population Economics 26(1): 285-201.

Currie J, and J. Gruber. 1996. "Saving Babies: The Efficacy and Cost of Recent Changes in the Medicaid Eligibility of Pregnant Women..” Journal of Political Economy 104(6), pp.1263-1296.

Cutler D., and J. Gruber. 1996. "Does Public Insurance Crowd Out Private Insurance? "Quarterly Journal of Economics 111(2): 391-430.

Dave D., S. Decker, R. Kaestner, and K. Simon. 2011. "The Effect of Medicaid Expansions on Health Insurance Coverage of Pregnant Women: An Analysis Using Deliveries.” Inquiry 47(4): 315-330.

Decker S. L. and F. W. Selck. 2011. "The Effect of the Original Introduction of Medicaid on Welfare Participation and Female Labor Supply." Review of Economics of the Household. 10(4): 541-556.

DeLeire, Thomas, Leonard M. Lopoo, Kosali I. Simon. 2011. "Medicaid Expansions and Fertility in the United States." Demography 48(2): 725-747.

Donald S.G. and K. Lang. 2007. "Inferences with Difference in Differences and Other Panel Data." The Review of Economics and Statistics 89(2): 221-233.

Dubay L, and G. Kenney. 1997. "Did the Medicaid Expansions for Pregnant Women Crowd out Private Insurance?" Health Affairs 16(1): 185-193.

Evers, Michiel, Ruud De Mooij, and Daniel Van Vuuren. "The Wage Elasticity of Labour Supply: A Synthesis of Empirical Estimates.” De Economist 156(1): 25-43.

Gruber J., and K. Simon. 2008. “Crowd out Ten Years Later: Have Recent Public Insurance Expansions Crowded Out Private Health Insurance?” Journal of Health Economics 27(2): 201-217

Ham, J.C., and L. Shore-Sheppard. 2005. "The Effect of Medicaid Expansions for Low-Income Children on Medicaid Participation and Private Insurance Coverage: Evidence from the SIPP." Journal of Public Economics 89 (1): $57-83$

Joyce T., R. Kaestner, and F. Kwan. 1998. "Is Medicaid Pronatalist? The Effect of Eligibility Expansions on Abortions and Births." Family Planning Perspectives 30(3): 108-113. 
Kapur, K. and J. Rogowski. 2007. "The Role of Health Insurance in Joint Retirement among Married Couples." Industrial and Labor Relations Review, 60(3): 397-407.

Lo Sasso, A.T., and T.C. Buchmueller. 2004. "The Effect of the State Children's Health Insurance Program on Health Insurance Coverage.” Journal of Health Economics 23(5): 1059-82.

Madrian, B. 2007. The U.S. Health Care System and Labor Markets. In J. S. Little, editor, Wanting It All: The Challenge of Reforming the U.S. Health Care System, Federal Reserve Bank of Boston: 137164.

Montgomery E. and J.C. Navin. 2000. "Cross-State Variation in Medicaid Programs and Female Labor Supply.” Economic Inquiry 38(30): 402-418.

Meyer B. D., Rosenbaum D.T., 2001. "Welfare, the Earned Income Tax Credit, and the $\quad$ Labor $\quad$ Supply of Single Mothers." Quarterly Journal of Economics, 116(3): 1063-1114.

Moffitt R., and B. Wolfe. 1992. "The Effect of the Medicaid Program on Welfare Participation and Labor Supply." The Review of Economics and Statistics 74(4): 615-626.

Moulton B.R. 1990. "An Illustration of a Pitfall in Estimating the Effects of Aggregate Variables in Micro Units." Review of Economics and Statistics 72(2): 334-338.

Shore-Sheppard L. 2008. "Stemming the Tide? The Effect of Expanding Medicaid Eligibility on Health Insurance Coverage." The B.E. Journal of Economic Analysis and Policy 8(2): Article 6.

Shore-Sheppard L, Buchmueller T.C., Jensen G.A. 2000. "Medicaid and Crowding Out of Private Insurance: A Re-examination Using Firm Level Data." Journal of Health Economics, 19(1): 61-91.

Strumpf E. 2011. "Medicaid's Effect on Single Women's Labor Supply: Evidence from the Introduction of Medicaid." Journal of Health Economics 30(3): 531-48.

Strumpf, E. 2010. "Employer-Sponsored Health Insurance for Early Retirees: Impacts on Retirement, Health, and Health Care.” International Journal of Health Care Finance and Economics. 10(2): 105-147.

Tomohara A. and H.J. Lee. 2007. “Did State Children's Health Insurance Program Affect Married Women's Labor Supply?” Journal of Family and Economic Issues 28: 668-683.

Winkler A.E. 1991. "The Incentive Effects of Medicaid on Women's Labor Supply." The Journal of Human Resources 26(2): 308-337.

Yelowitz A. 1995. "The Medicaid Notch, Labor Supply, and Welfare Participation: Evidence from Eligibility Expansions" The Quarterly Journal of Economics 110(4): 909-939.

Zavodny, M. and M. Bitler. 2010. "The Effect of Medicaid Eligibility Expansions on Fertility." Social Science and Medicine 71(5): 918-924. 
Figure 1: $\quad$ Fraction of Pregnant Women Eligible for Medicaid Coverage CPS: 1985 - 1996

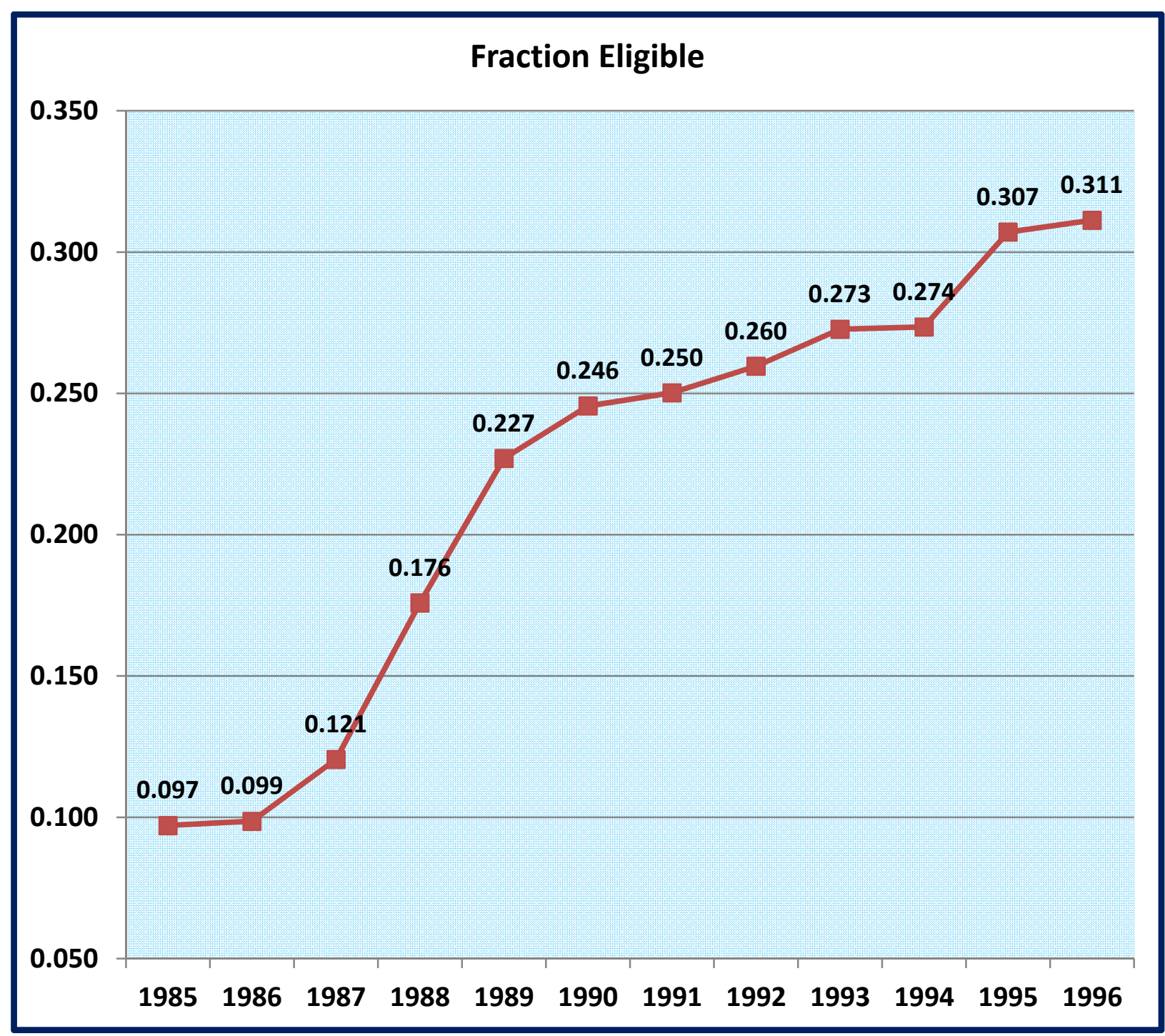


Table 1

Weighted Means

CPS 1986 - 1997

\begin{tabular}{|c|c|c|c|c|c|}
\hline Sample & All & Unmarried & $\begin{array}{l}\text { Less than } \\
\text { High School }\end{array}$ & Black & Other Race \\
\hline Employed last year & 0.656 & 0.537 & 0.523 & 0.578 & 0.602 \\
\hline Labor force participation last year & 0.677 & 0.591 & 0.554 & 0.631 & 0.626 \\
\hline Weeks worked last year & 24.451 & 17.787 & 17.396 & 20.781 & 23.077 \\
\hline Usual weekly hours worked last year & 22.741 & 18.909 & 18.028 & 21.126 & 22.163 \\
\hline Wages & 8541.019 & 4514.989 & 3904.556 & 6278.060 & 9499.078 \\
\hline Log Wages & 4.710 & 3.382 & 3.045 & 4.005 & 4.335 \\
\hline Simulated \% Medicaid eligible & 0.221 & 0.302 & 0.201 & 0.424 & 0.258 \\
\hline Unmarried & 0.181 & 1.000 & 0.260 & 0.589 & 0.123 \\
\hline Less than high school & 0.380 & 0.548 & 1.000 & 0.466 & 0.330 \\
\hline Black & 0.127 & 0.414 & 0.156 & 1.000 & 0.000 \\
\hline Other race & 0.042 & 0.029 & 0.037 & 0.000 & 1.000 \\
\hline Age & 27.946 & 25.531 & 26.249 & 26.703 & 28.714 \\
\hline State unemployment rate & 6.415 & 6.421 & 6.531 & 6.486 & 6.528 \\
\hline State poverty rate & 19.981 & 14.229 & 17.817 & 16.241 & 19.717 \\
\hline $\begin{array}{l}\text { State } \% \text { men aged } 25-64 \text { and }<200 \% \text { with private } \\
\text { insurance }\end{array}$ & 0.308 & 0.301 & 0.309 & 0.296 & 0.304 \\
\hline
\end{tabular}

Notes: Weighted sample means are reported. There are 24,177 observations for women age 18-39 with a child less than one year old. 
Table 2

Effect of Medicaid on Mothers’ Employment \& Labor Force Participation

\begin{tabular}{|c|c|c|c|c|c|c|}
\hline Outcome & \multicolumn{2}{|c|}{ Employed last year } & \multicolumn{2}{|c|}{ Labor force participation last year } & \multicolumn{2}{|c|}{ Weeks worked last year } \\
\hline Model & 1 & 2 & 3 & 4 & 5 & 6 \\
\hline Simulated \% Medicaid eligible & $\begin{array}{c}-0.2214 * * * \\
(0.0656)\end{array}$ & $\begin{array}{c}-0.2054 * * * \\
(0.0697)\end{array}$ & $\begin{array}{c}-0.2035 * * * \\
(0.0532)\end{array}$ & $\begin{array}{c}-0.1796 * * * \\
(0.0586)\end{array}$ & $\begin{array}{l}-0.3990 * \\
(0.2195)\end{array}$ & $\begin{array}{l}-0.3384 \\
(0.2335)\end{array}$ \\
\hline Unmarried & $\begin{array}{c}0.0828 * * * \\
(0.0127)\end{array}$ & $\begin{array}{c}0.0826 * * * \\
(0.0129)\end{array}$ & $\begin{array}{c}0.0958 * * * \\
(0.0139)\end{array}$ & $\begin{array}{c}0.0959 * * * \\
(0.0140)\end{array}$ & $\begin{array}{c}0.2392 * * * \\
(0.0525)\end{array}$ & $\begin{array}{c}0.2411 * * * \\
(0.0523)\end{array}$ \\
\hline Less than high school & $\begin{array}{c}-0.1396 * * * \\
(0.0116)\end{array}$ & $\begin{array}{c}-0.1395 * * * \\
(0.0115)\end{array}$ & $\begin{array}{c}-0.1359 * * * \\
(0.0113)\end{array}$ & $\begin{array}{c}-0.1353 * * * \\
(0.0113)\end{array}$ & $\begin{array}{c}-0.3353 * * * \\
(0.0290)\end{array}$ & $\begin{array}{c}-0.3349 * * \\
(0.0297)\end{array}$ \\
\hline Age & $\begin{array}{c}-0.0016 * * \\
(0.0006)\end{array}$ & $\begin{array}{c}-0.0016 * * \\
(0.0006)\end{array}$ & $\begin{array}{c}-0.0025 * * * \\
(0.0006)\end{array}$ & $\begin{array}{c}-0.0025 * * * \\
(0.0006)\end{array}$ & $\begin{array}{c}0.0119 * * * \\
(0.0013)\end{array}$ & $\begin{array}{c}0.0118 * * * \\
(0.0013)\end{array}$ \\
\hline Black & $\begin{array}{c}0.0581 * * * \\
(0.0158)\end{array}$ & $\begin{array}{c}0.0534 * * * \\
(0.0173)\end{array}$ & $\begin{array}{c}0.0731 * * * \\
(0.0144)\end{array}$ & $\begin{array}{c}0.0665 * * * \\
(0.0151)\end{array}$ & $\begin{array}{c}0.1175 * * * \\
(0.0361)\end{array}$ & $\begin{array}{c}0.1018 * * * \\
(0.0376)\end{array}$ \\
\hline Other race & $\begin{array}{l}-0.0115 \\
(0.0240)\end{array}$ & $\begin{array}{c}-0.0123 \\
(0.0245)\end{array}$ & $\begin{array}{c}-0.0055 \\
(0.0194)\end{array}$ & $\begin{array}{c}-0.0071 \\
(0.0199)\end{array}$ & $\begin{array}{c}0.0213 \\
(0.0456)\end{array}$ & $\begin{array}{c}0.0150 \\
(0.0430)\end{array}$ \\
\hline Unemployment rate & $\begin{array}{c}-0.0070 * * \\
(0.0028)\end{array}$ & $\begin{array}{l}-0.0025 \\
(0.0048)\end{array}$ & $\begin{array}{c}-0.0029 \\
(0.0028)\end{array}$ & $\begin{array}{c}0.0029 \\
(0.0050)\end{array}$ & $\begin{array}{c}-0.0201 * * * \\
(0.0074)\end{array}$ & $\begin{array}{l}-0.0157 \\
(0.0109)\end{array}$ \\
\hline$\%$ Under poverty & $\begin{array}{c}0.0285 * * * \\
(0.0009)\end{array}$ & $\begin{array}{c}0.0285 * * * \\
(0.0009)\end{array}$ & $\begin{array}{c}0.0259 * * * \\
(0.0010)\end{array}$ & $\begin{array}{c}0.0259 * * * \\
(0.0010)\end{array}$ & $\begin{array}{c}0.0891 * * * \\
(0.0033)\end{array}$ & $\begin{array}{c}0.0898 * * * \\
(0.0032)\end{array}$ \\
\hline$\%$ Men ages $25-64$ and $<200 \%$ & -0.0489 & -0.0652 & -0.0542 & -0.0734 & -0.1551 & -0.2033 \\
\hline Poverty with private insurance & $(0.0498)$ & $(0.0541)$ & $(0.0528)$ & $(0.0565)$ & $(0.1289)$ & $(0.1365)$ \\
\hline State-specific linear time trend & No & Yes & No & Yes & No & Yes \\
\hline Estimation & \multicolumn{2}{|c|}{ OLS } & \multicolumn{2}{|c|}{ OLS } & \multicolumn{2}{|c|}{ Negative Binomial } \\
\hline
\end{tabular}

Notes: All models adjust for sampling weights. State and year effects are included, as well as controls for marital status, education, race, and state

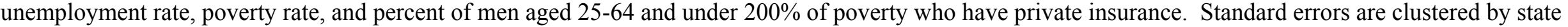

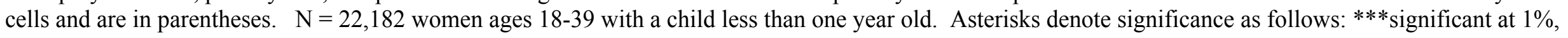
** significant at 5\%, * significant at $10 \%$. 
Table 3

Effect of Medicaid on Mothers' Hours Worked and Wages

\begin{tabular}{|c|c|c|c|c|c|c|c|c|}
\hline Outcome & \multicolumn{2}{|c|}{$\begin{array}{l}\text { Usual weekly hours worked } \\
\text { last year }\end{array}$} & \multicolumn{2}{|c|}{$\begin{array}{c}\text { Usual weekly hours worked } \\
\text { last year } \\
\text { (Conditional on Hours }>0 \text { ) }\end{array}$} & \multicolumn{2}{|c|}{$\begin{array}{c}\text { Log Wages } \\
\text { (0 wage included) }\end{array}$} & \multicolumn{2}{|c|}{$\begin{array}{c}\text { Log Wages } \\
(\text { Conditional on Wages }>0)\end{array}$} \\
\hline Model & 1 & 2 & 3 & 4 & 5 & 6 & 7 & 8 \\
\hline Simulated \% Medicaid eligible & $\begin{array}{c}-0.5225 * * * \\
(0.1782)\end{array}$ & $\begin{array}{l}-0.5108^{* *} \\
(0.2062)\end{array}$ & $\begin{array}{l}-0.0801 \\
(0.0559)\end{array}$ & $\begin{array}{l}-0.1182 * * \\
(0.0572)\end{array}$ & $\begin{array}{c}-2.5799 * * * \\
(0.7888)\end{array}$ & $\begin{array}{c}-2.6247^{* * *} \\
(0.8180)\end{array}$ & $\begin{array}{l}-0.2499 \\
(0.1867)\end{array}$ & $\begin{array}{l}-0.4208^{*} \\
(0.2162)\end{array}$ \\
\hline Unmarried & $\begin{array}{c}0.2239 * * * \\
(0.0380)\end{array}$ & $\begin{array}{c}0.2232 * * * \\
(0.0384)\end{array}$ & $\begin{array}{c}0.0520 * * * \\
(0.0131)\end{array}$ & $\begin{array}{c}0.0521 * * * \\
(0.0130)\end{array}$ & $\begin{array}{l}1.1919 * * * \\
(0.1281)\end{array}$ & $\begin{array}{c}1.1883 * * * \\
(0.1313)\end{array}$ & $\begin{array}{c}0.1594 * * * \\
(0.0366)\end{array}$ & $\begin{array}{c}0.1598 * * * \\
(0.0365)\end{array}$ \\
\hline Less than high school & $\begin{array}{c}-0.2501 * * * \\
(0.0244)\end{array}$ & $\begin{array}{c}-0.2493 * * * \\
(0.0248)\end{array}$ & $\begin{array}{r}0.0130 * * \\
(0.0062)\end{array}$ & $\begin{array}{c}0.0133 * * \\
(0.0062)\end{array}$ & $\begin{array}{c}-1.6232 * * * \\
(0.1144)\end{array}$ & $\begin{array}{c}-1.6211 * * * \\
(0.1148)\end{array}$ & $\begin{array}{c}-0.3501 * * * \\
(0.0285)\end{array}$ & $\begin{array}{c}-0.3507 * * * \\
(0.0284)\end{array}$ \\
\hline Age & $\begin{array}{c}-0.0026^{* *} \\
(0.0012)\end{array}$ & $\begin{array}{c}-0.0027^{* *} \\
(0.0012)\end{array}$ & $\begin{array}{c}0.0006 \\
(0.0007)\end{array}$ & $\begin{array}{c}0.0006 \\
(0.0007)\end{array}$ & $\begin{array}{l}-0.0073 \\
(0.0086)\end{array}$ & $\begin{array}{l}-0.0082 \\
(0.0087)\end{array}$ & $\begin{array}{c}0.0596 * * * \\
(0.0025)\end{array}$ & $\begin{array}{c}0.0592 * * * \\
(0.0026)\end{array}$ \\
\hline Black & $\begin{array}{c}0.1711 * * * \\
(0.0375)\end{array}$ & $\begin{array}{c}0.1677 * * * \\
(0.0397)\end{array}$ & $\begin{array}{c}0.0754 * * * \\
(0.0155)\end{array}$ & $\begin{array}{c}0.0840 * * * \\
(0.0154)\end{array}$ & $\begin{array}{c}0.9230 * * * \\
(0.2062)\end{array}$ & $\begin{array}{c}0.9236 * * * \\
(0.1999)\end{array}$ & $\begin{array}{c}0.1570 * * * \\
(0.0432)\end{array}$ & $\begin{array}{c}0.1982 * * * \\
(0.0513)\end{array}$ \\
\hline Other race & $\begin{array}{c}0.0680 \\
(0.0537)\end{array}$ & $\begin{array}{c}0.0708 \\
(0.0543)\end{array}$ & $\begin{array}{c}0.0734 * * * \\
(0.0125)\end{array}$ & $\begin{array}{c}0.0763 * * * \\
(0.0133)\end{array}$ & $\begin{array}{c}0.1321 \\
(0.3239)\end{array}$ & $\begin{array}{c}0.1405 \\
(0.3265)\end{array}$ & $\begin{array}{c}0.1019 * * \\
(0.0393)\end{array}$ & $\begin{array}{c}0.1098 * * * \\
(0.0371)\end{array}$ \\
\hline Unemployment rate & $\begin{array}{c}-0.0149 * * \\
(0.0064)\end{array}$ & $\begin{array}{l}-0.0089 \\
(0.0117)\end{array}$ & $\begin{array}{l}-0.0022 \\
(0.0030)\end{array}$ & $\begin{array}{l}-0.0039 \\
(0.0043)\end{array}$ & $\begin{array}{c}-0.0881 * * \\
(0.0341)\end{array}$ & $\begin{array}{l}-0.0664 \\
(0.0533)\end{array}$ & $\begin{array}{c}-0.0231 * \\
(0.0121)\end{array}$ & $\begin{array}{l}-0.0265 \\
(0.0167)\end{array}$ \\
\hline $\begin{array}{l}\% \text { Under poverty } \\
\% \text { Men ages } 25-64 \text { and }<200 \% \\
\text { Poverty with private insurance }\end{array}$ & $\begin{array}{c}0.0662 * * * \\
(0.0043) \\
-0.1386 \\
(0.1018)\end{array}$ & $\begin{array}{c}0.0664 * * * \\
(0.0043) \\
-0.1866 * \\
(0.1069)\end{array}$ & $\begin{array}{c}0.0103 * * * \\
(0.0010) \\
-0.0305 \\
(0.0533)\end{array}$ & $\begin{array}{c}0.0102 * * * \\
(0.0010) \\
-0.0295 \\
(0.0531)\end{array}$ & $\begin{array}{c}0.3695 * * * \\
(0.0082) \\
-0.2441 \\
(0.5720)\end{array}$ & $\begin{array}{c}0.3688 * * * \\
(0.0081) \\
-0.2963 \\
(0.5995)\end{array}$ & $\begin{array}{c}0.1096 * * * \\
(0.0036) \\
-0.1026 \\
(0.1708)\end{array}$ & $\begin{array}{c}0.1099 * * * \\
(0.0036) \\
-0.1286 \\
(0.1841)\end{array}$ \\
\hline $\begin{array}{l}\text { State-specific linear time trend } \\
\text { Estimation }\end{array}$ & $\begin{array}{l}\text { No } \\
\text { Negativ }\end{array}$ & inomial & $\begin{array}{l}\text { No } \\
\text { Negati }\end{array}$ & inomial & No & Yes & No & Yes \\
\hline
\end{tabular}

Notes: All models adjust for sampling weights. State and year effects are included, as well as controls for marital status, education, race, and state

unemployment rate, poverty rate, and percent of men aged 25-64 and under 200\% of poverty who have private insurance. Standard errors are clustered by state cells and are in parentheses. $\mathrm{N}=22,182$ women ages 18-39 with a child less than one year old; for models conditional on positive hours worked (wages),

$\mathrm{N}=14,477(13,753)$. Asterisks denote significance as follows: $* * *$ significant at $1 \%$, $* *$ significant at $5 \%, *$ significant at $10 \%$. 
Table 4

Controlling for State*Age and Year*Age Effects

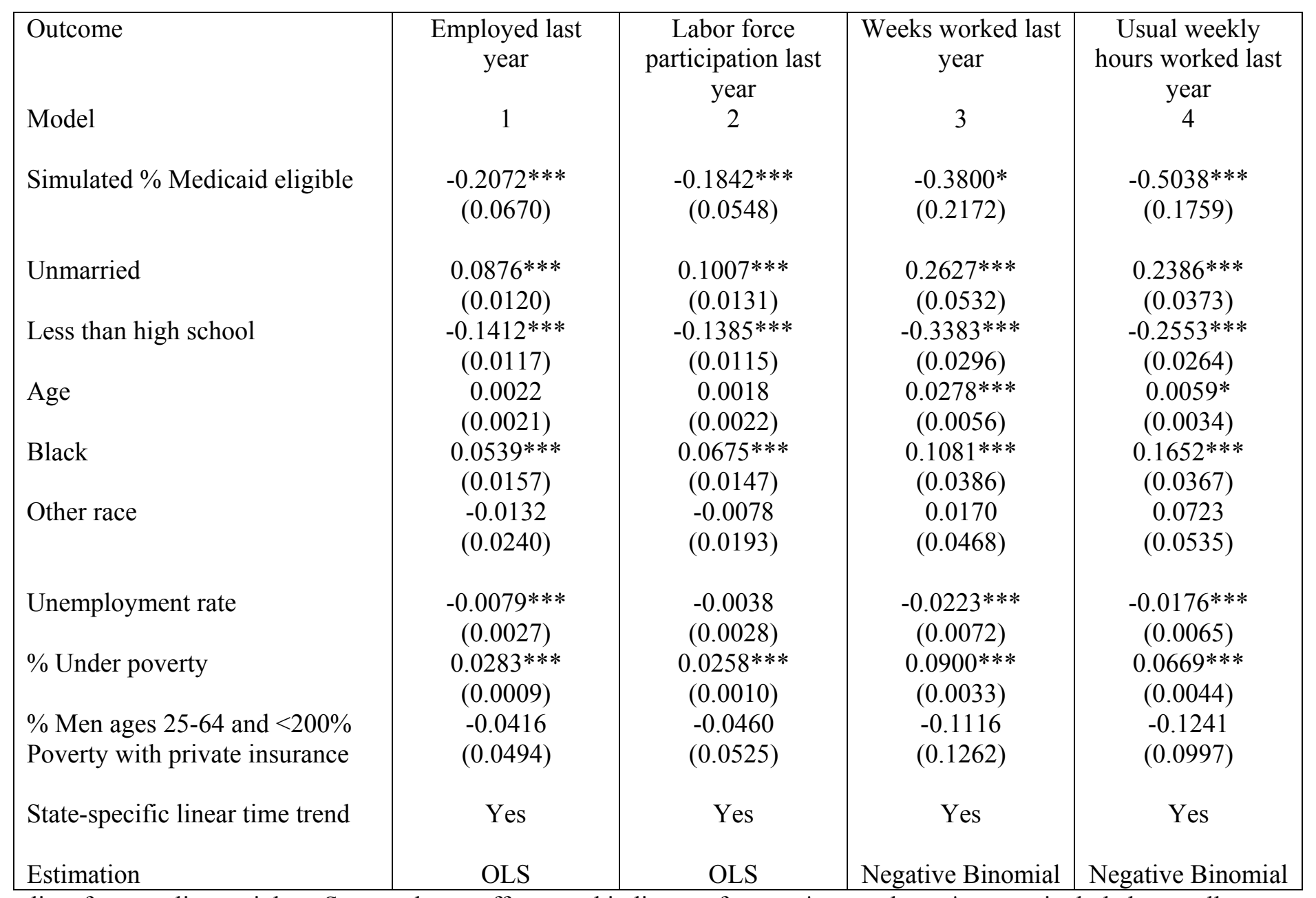

Notes: All models adjust for sampling weights. State and year effects, and indicators for state*age and year*age are included, as well as controls for marital status, education, race, and state unemployment rate, poverty rate, and percent of men aged 25-64 and under 200\% of poverty who have private insurance. Standard errors are clustered by state cells and are in parentheses. $\mathrm{N}=22,182$ women ages 18-39 with a child less than one year old. Asterisks denote significance as follows: *** significant at $1 \%, * *$ significant at $5 \%, *$ significant at $10 \%$. 
Table 5

Differential Effects by Marital Status \& Education

\begin{tabular}{|c|c|c|c|c|c|c|c|c|}
\hline Outcome & \multicolumn{2}{|c|}{ Employed last year } & \multicolumn{2}{|c|}{$\begin{array}{l}\text { Labor force participation last } \\
\text { year }\end{array}$} & \multicolumn{2}{|c|}{ Weeks worked last year } & \multicolumn{2}{|c|}{$\begin{array}{c}\text { Usual weekly hours worked } \\
\text { last year }\end{array}$} \\
\hline Model & 1 & 2 & 3 & 4 & 5 & 6 & 7 & 8 \\
\hline Unmarried & $\begin{array}{c}0.1416 * * * \\
(0.0228)\end{array}$ & $\begin{array}{l}0.1407 * * * \\
(0.0231)\end{array}$ & $\begin{array}{l}0.1594 * * * \\
(0.0243)\end{array}$ & $\begin{array}{l}0.1579 * * * \\
(0.0246)\end{array}$ & $\begin{array}{c}0.3758 * * * \\
(0.0843)\end{array}$ & $\begin{array}{c}0.3813 * * * \\
(0.0848)\end{array}$ & $\begin{array}{c}0.3565 * * * \\
(0.0615)\end{array}$ & $\begin{array}{l}0.3550 * * * \\
(0.0631)\end{array}$ \\
\hline Unmarried $* \%$ Medicaid eligible & $\begin{array}{c}-0.2262 * * * \\
(0.0717)\end{array}$ & $\begin{array}{c}-0.2235 * * * \\
(0.0738)\end{array}$ & $\begin{array}{c}-0.2447 * * * \\
(0.0712)\end{array}$ & $\begin{array}{c}-0.2390 * * * \\
(0.0731)\end{array}$ & $\begin{array}{c}-0.5250 * * \\
(0.2257)\end{array}$ & $\begin{array}{c}-0.5393 * * \\
(0.2338)\end{array}$ & $\begin{array}{c}-0.5116 * * * \\
(0.1797)\end{array}$ & $\begin{array}{c}-0.5084 * * * \\
(0.1849)\end{array}$ \\
\hline Simulated \% Medicaid eligible & $\begin{array}{l}-0.0921 \\
(0.0614)\end{array}$ & $\begin{array}{l}-0.0646 \\
(0.0684)\end{array}$ & $\begin{array}{l}-0.0813 \\
(0.0546)\end{array}$ & $\begin{array}{l}-0.0468 \\
(0.0613)\end{array}$ & $\begin{array}{l}-0.0403 \\
(0.2065)\end{array}$ & $\begin{array}{c}0.0677 \\
(0.2162)\end{array}$ & $\begin{array}{l}-0.1622 \\
(0.1520)\end{array}$ & $\begin{array}{l}-0.1046 \\
(0.1850)\end{array}$ \\
\hline Less than High School & $\begin{array}{c}-0.0694 * * * \\
(0.0143)\end{array}$ & $\begin{array}{c}-0.0682 * * * \\
(0.0144)\end{array}$ & $\begin{array}{c}-0.0695 * * * \\
(0.0149)\end{array}$ & $\begin{array}{c}-0.0682 * * * \\
(0.0147)\end{array}$ & $\begin{array}{c}-0.1376 * * * \\
(0.0375)\end{array}$ & $\begin{array}{c}-0.1310 * * * \\
(0.0377)\end{array}$ & $\begin{array}{l}-0.0444 \\
(0.0330)\end{array}$ & $\begin{array}{l}-0.0393 \\
(0.0323)\end{array}$ \\
\hline $\begin{array}{l}\text { Less than High School } * \\
\% \text { Medicaid eligible }\end{array}$ & $\begin{array}{c}-0.3403 * * * \\
(0.0594)\end{array}$ & $\begin{array}{c}-0.3453 * * * \\
(0.0588)\end{array}$ & $\begin{array}{c}-0.3213 * * * \\
(0.0572)\end{array}$ & $\begin{array}{c}-0.3255 * * * \\
(0.0568)\end{array}$ & $\begin{array}{c}-0.9676 * * * \\
(0.1782)\end{array}$ & $\begin{array}{c}-0.9983 * * * \\
(0.1779)\end{array}$ & $\begin{array}{c}-0.9976 * * * \\
(0.1716)\end{array}$ & $\begin{array}{c}-1.0194 * * * \\
(0.1693)\end{array}$ \\
\hline State-specific linear time trend & No & Yes & No & Yes & No & Yes & No & Yes \\
\hline Estimation & \multicolumn{2}{|c|}{ OLS } & \multicolumn{2}{|c|}{ OLS } & \multicolumn{2}{|c|}{ Negative Binomial } & \multicolumn{2}{|c|}{ Negative Binomial } \\
\hline
\end{tabular}

Notes: All models adjust for sampling weights. State and year effects are included, as well as controls for marital status, education, race, and state

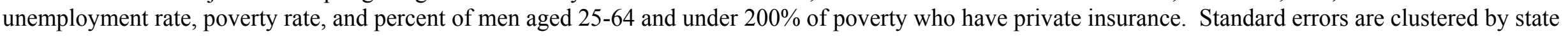

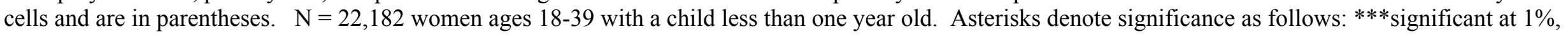

** significant at 5\%, * significant at $10 \%$. 
Table 6

Differential Effects by $1^{\text {st }}$ child and $>1$ children

\begin{tabular}{|c|c|c|c|c|c|c|c|c|}
\hline Sample & \multicolumn{4}{|c|}{$1^{\text {st }}$ Child } & \multicolumn{4}{|c|}{ Not $1^{\text {st }}$ Child } \\
\hline Outcome & $\begin{array}{l}\text { Employed } \\
\text { last year }\end{array}$ & $\begin{array}{c}\text { Labor force } \\
\text { participation } \\
\text { last year }\end{array}$ & $\begin{array}{c}\text { Weeks } \\
\text { worked last } \\
\text { year }\end{array}$ & $\begin{array}{c}\text { Usual weekly } \\
\text { hours worked } \\
\text { last year }\end{array}$ & $\begin{array}{l}\text { Employed } \\
\text { last year }\end{array}$ & $\begin{array}{c}\text { Labor force } \\
\text { participation } \\
\text { last year }\end{array}$ & $\begin{array}{c}\text { Weeks } \\
\text { worked last } \\
\text { year }\end{array}$ & $\begin{array}{c}\text { Usual weekly } \\
\text { hours worked } \\
\text { last year }\end{array}$ \\
\hline Model & 1 & 2 & 3 & 4 & 5 & 6 & 7 & 8 \\
\hline $\begin{array}{l}\text { Simulated \% } \\
\text { Medicaid } \\
\text { Eligible }\end{array}$ & $\begin{array}{c}-0.2054 * * \\
(0.0978)\end{array}$ & $\begin{array}{c}-0.2353 * * \\
(0.0953)\end{array}$ & $\begin{array}{c}-0.3302 * \\
(0.1871)\end{array}$ & $\begin{array}{c}-0.4039 * * \\
(0.1821)\end{array}$ & $\begin{array}{c}-0.1825^{* *} \\
(0.0757)\end{array}$ & $\begin{array}{c}-0.4441^{*} \\
(0.2694)\end{array}$ & $\begin{array}{c}-0.5701 * * \\
(0.2222)\end{array}$ & $\begin{array}{c}-0.2054 * * \\
(0.0978)\end{array}$ \\
\hline Observations & 8165 & 8165 & 8165 & 8165 & 14017 & 14017 & 14017 & 14017 \\
\hline Estimation & OLS & OLS & $\begin{array}{l}\text { Negative } \\
\text { Binomial }\end{array}$ & $\begin{array}{l}\text { Negative } \\
\text { Binomial }\end{array}$ & OLS & OLS & $\begin{array}{l}\text { Negative } \\
\text { Binomial }\end{array}$ & $\begin{array}{l}\text { Negative } \\
\text { Binomial }\end{array}$ \\
\hline
\end{tabular}

Notes: All models adjust for sampling weights. State and year effects are included, as well as controls for marital status, education, race, and state

unemployment rate, poverty rate, and percent of men aged 25-64 and under 200\% of poverty who have private insurance. Standard errors are clustered by state cells and are in parentheses. Asterisks denote significance as follows: ${ }^{* *}$ significant at $1 \%$, $* *$ significant at $5 \%,{ }^{*}$ significant at $10 \%$. 
Table 7

Effect of Medicaid on Joint Outcomes: Labor Supply \& Health Insurance Status

Multinomial Logit Estimates

\begin{tabular}{|c|c|c|c|c|c|c|c|}
\hline \multirow[t]{2}{*}{ Panel A } & & \multicolumn{6}{|c|}{ Employed Last Year*Insurance Status } \\
\hline & $\begin{array}{l}\text { Employed Last Year } \\
\text { Health Insurance }\end{array}$ & $\begin{array}{c}\text { Yes } \\
\text { Private }\end{array}$ & $\begin{array}{l}\text { Yes } \\
\text { Public }\end{array}$ & $\begin{array}{l}\text { Yes } \\
\text { None }\end{array}$ & $\begin{array}{c}\text { No } \\
\text { Private }\end{array}$ & $\begin{array}{l}\text { No } \\
\text { Public }\end{array}$ & $\begin{array}{l}\text { No } \\
\text { None }\end{array}$ \\
\hline $\begin{array}{l}\text { No State- } \\
\text { specific } \\
\text { Linear Trends }\end{array}$ & $\begin{array}{l}\text { Simulated \% Medicaid } \\
\text { Eligible }\end{array}$ & $\begin{array}{c}-0.3568 * * * \\
(0.1009)\end{array}$ & $\begin{array}{c}0.0903 * * * \\
(0.0335)\end{array}$ & $\begin{array}{c}0.0601 \\
(0.0447)\end{array}$ & $\begin{array}{l}-0.0013 \\
(0.0578)\end{array}$ & $\begin{array}{c}0.1419 * * * \\
(0.0383)\end{array}$ & $\begin{array}{c}0.0657 * * * \\
(0.0247)\end{array}$ \\
\hline \multirow[t]{2}{*}{$\begin{array}{l}\text { State-specific } \\
\text { Linear Trends }\end{array}$} & $\begin{array}{l}\text { Simulated \% Medicaid } \\
\text { Eligible }\end{array}$ & $\begin{array}{c}-0.3618 * * * \\
(0.1117)\end{array}$ & $\begin{array}{l}0.0850 * * \\
(0.0375)\end{array}$ & $\begin{array}{c}0.0743 \\
(0.0464)\end{array}$ & $\begin{array}{l}-0.0007 \\
(0.0629)\end{array}$ & $\begin{array}{c}0.1323 * * * \\
(0.0365)\end{array}$ & $\begin{array}{l}0.0709 * * \\
(0.0291)\end{array}$ \\
\hline & $\%$ in category in 1986 & $53.16 \%$ & $4.84 \%$ & $6.13 \%$ & $20.08 \%$ & $9.81 \%$ & $5.99 \%$ \\
\hline \multirow[t]{2}{*}{ Panel B } & Outcome & \multicolumn{6}{|c|}{ Labor Force Participation*Insurance Status } \\
\hline & $\begin{array}{l}\text { Lab. Force Part. Last } \\
\text { Year } \\
\text { Health Insurance }\end{array}$ & $\begin{array}{c}\text { Yes } \\
\text { Private }\end{array}$ & $\begin{array}{c}\text { Yes } \\
\text { Public }\end{array}$ & $\begin{array}{l}\text { Yes } \\
\text { None }\end{array}$ & $\begin{array}{l}\text { No } \\
\text { Private }\end{array}$ & $\begin{array}{c}\text { No } \\
\text { Public }\end{array}$ & $\begin{array}{l}\text { No } \\
\text { None }\end{array}$ \\
\hline $\begin{array}{l}\text { No State- } \\
\text { specific } \\
\text { Linear Trends }\end{array}$ & $\begin{array}{l}\text { Simulated \% Medicaid } \\
\text { Eligible }\end{array}$ & $\begin{array}{c}-0.3335 * * * \\
(0.1029)\end{array}$ & $\begin{array}{c}0.1035 * * * \\
(0.0372)\end{array}$ & $\begin{array}{c}0.0573 \\
(0.0446)\end{array}$ & $\begin{array}{l}-0.0236 \\
(0.0541)\end{array}$ & $\begin{array}{c}0.1299 * * * \\
(0.0327)\end{array}$ & $\begin{array}{c}0.0664 * * * \\
(0.0247)\end{array}$ \\
\hline $\begin{array}{l}\text { State-specific } \\
\text { Linear Trends }\end{array}$ & $\begin{array}{l}\text { Simulated \% Medicaid } \\
\text { Eligible }\end{array}$ & $\begin{array}{c}-0.3297 * * * \\
(0.1136)\end{array}$ & $\begin{array}{c}0.0996 * * * \\
(0.0385)\end{array}$ & $\begin{array}{c}0.0738 \\
(0.0464)\end{array}$ & $\begin{array}{l}-0.0312 \\
(0.0599)\end{array}$ & $\begin{array}{c}0.1184 * * * \\
(0.0319)\end{array}$ & $\begin{array}{l}0.0691 * * \\
(0.0284)\end{array}$ \\
\hline & $\%$ in category in 1986 & $53.91 \%$ & $5.96 \%$ & $6.65 \%$ & $19.32 \%$ & $8.69 \%$ & $5.47 \%$ \\
\hline
\end{tabular}

Notes: Marginal effects from multinomial logit models are reported. All models utilize sampling weights, and control for state and year fixed effects in addition to the covariates listed in Table 2. Standard errors are clustered at the state level and reported in parentheses. N=22,182 women ages 18-39 with a child less than one year old. Asterisks denote significance as follows: $* * *$ significant at $1 \%, * *$ significant at $5 \%,{ }^{*}$ significant at $10 \%$. 
Table 8

Effect of Medicaid on Males' Labor Supply

Placebo Test

\begin{tabular}{|c|c|c|c|c|}
\hline Sample & \multicolumn{4}{|c|}{$\begin{array}{c}\text { Males } \\
\text { Ages 18-39 } \\
\text { Unmarried } \\
\text { Less than High School }\end{array}$} \\
\hline Outcome & $\begin{array}{c}\text { Employed last } \\
\text { year }\end{array}$ & $\begin{array}{l}\text { Labor force } \\
\text { participation } \\
\text { last year }\end{array}$ & $\begin{array}{l}\text { Weeks worked } \\
\text { last year }\end{array}$ & $\begin{array}{l}\text { Usual weekly } \\
\text { hours worked } \\
\text { last year }\end{array}$ \\
\hline $\begin{array}{l}\text { Pregnant Women } \\
\text { Simulated \% } \\
\text { Medicaid Eligible }\end{array}$ & $\begin{array}{l}-0.0053 \\
(0.0296)\end{array}$ & $\begin{array}{c}0.0317 \\
(0.0264)\end{array}$ & $\begin{array}{l}-0.0659 \\
(0.0500)\end{array}$ & $\begin{array}{l}-0.0107 \\
(0.0420)\end{array}$ \\
\hline Estimation & OLS & OLS & $\begin{array}{l}\text { Negative } \\
\text { Binomial }\end{array}$ & $\begin{array}{l}\text { Negative } \\
\text { Binomial }\end{array}$ \\
\hline
\end{tabular}

Notes: All models utilize sampling weights, and control for state and year fixed effects and state-specific linear trends in addition to the covariates listed in the text. Standard errors are clustered at the state level and reported in parentheses. $\mathrm{N}=50,358$ unmarried males $18-39$ with less than a high school education. $* * *$ significant at $1 \%$, $* *$ significant at $5 \%, *$ significant at $10 \%$. 